\title{
Survival of Oral Human Immune Serum Globulin in the Gastrointestinal Tract of Low Birth Weight Infants
}

\author{
PAUL M. BLUM, DALE L. PHELPS, BONNIE J. ANK, HERBERT J. KRANTMAN, AND \\ E. RICHARD'STIEHM ${ }^{(24)}$ \\ The Divisions of Allergy/Immunology and Neonatology, UCLA Department of Pediatrics at the Center for the Health \\ Sciences, and the UCLA Center for Interdisciplinary Research in Immunologic Diseases, Los Angeles, \\ California, USA
}

\begin{abstract}
Summary
Six immature infants were given oral feedings of $10 \%$ preservative-free human immune serum globulin ranging from 1 to $8 \mathrm{ml} /$ $\mathrm{kg} /$ day. A seventh infant served as a control. Undigested and partially digested IgG was detected in the stools in significant quantities in all but the control infant. This coproantibody retained significant opsonic activity for type III group B streptococci as determined by a chemiluminescence assay, but lost most of its tetanus antibody activity. The newborn infants' enzymatic immaturity or rapid transit time permits the passage of intact IgG or partially digested IgG to pass throughout the gastrointestinal tract.
\end{abstract}

\section{Speculation}

The survival of intact IgG immunoglobulin in the stool of newborns after its oral administration may indicate that specific IgG antibody can serve as a colostral IgA substitute. Oral immunoglobulin may be of value in the prevention or treatment of enteric infections (e.g., Escherichia coli, V. cholera, S. typhosa, rotavirus) or intoxications (e.g., infantile botulism).

Breast-fed newborn infants are better protected against gastrointestinal infection than are formula-fed infants (5). This can be accounted for by the presence of $\mathrm{T}$ and $\mathrm{B}$ lymphocytes, phagocytes, antibodies, complement components, and other anti-bacterial substances such as lactoferrin and lysozyme. The relative importance of these elements in milk is difficult to assess, although removal of cells by heating or centrifugation may lead to a significant loss in protective ability (12). Nevertheless, there is considerable evidence that cell-free colostrum or bovine colostral whey protein may serve a protective role in providing passive immunity to the gastrointestinal (GI) tract. Colostrum is particularly rich in immunoglobulin, containing up to $500 \mathrm{mg} / \mathrm{dl}$ of primarily $11 \mathrm{~S}$ secretory $\operatorname{IgA}(1)$. In this form, IgA resists proteolytic digestion, making it the ideal additive for oral passive immunity. However, difficulties in procurement, isolation, sterilization, and standardization limit its usefulness as a potential infant formula additive. Indeed, the nonsterility of banked breast milk is a potential hazard. Commercially available gamma-globulin [human immune serum globulin (HISG)], which is predominantly IgG, has none of these limitations because it is readily available, free of hepatitis virus, is in a concentrated and stable form and is titered for several antibodies.

The present study was undertaken to determine if orally administered HISG could resist degradation sufficiently to provide some antimicrobial activity throughout the immature GI tract. Therefore, we gave HISG orally to six thriving premature infants and determined the amount of $\mathrm{IgG}$ recovered in the stool as well as its functional activity. We used a modified deaggregated HISG, originally produced for intravenous use (modified immune serum globulin, lot 2581, BBIND 501; Cutter Laboratories); as a $10 \%$ solution of glycine because it is free of mercury-containing thiomerosol preservative.

\section{MATERIALS AND METHODS}

PATIENTS AND PROTOCOL

Seven thriving formula-fed 4- to 13-wk-old immature infants (birth weight, 0.86 to $1.46 \mathrm{~kg}$; weight at study, 1.36 to $1.7 \mathrm{~kg}$ ) were selected from the transitional nursery population at UCLA (Table 1). None received breast milk in the 2 wk before this study. Parental informed consent was obtained in accordance with the guidelines of the UCLA Human Subject's Protection Committee. HISG in doses of from 1 to $8 \mathrm{ml} / \mathrm{kg} /$ day in divided doses was administered orally in formula feedings for 5 consecutive days to six infants. One infant (KF-\#1) one of triplets, served as control (see Table 1). Serum samples for quantitative immunoglobulin levels were obtained before the first HISG feeding and after the fifth day of HISG feeding. All stools were collected and saved for each 24-hr period beginning with the day before HISG feedings began and continuing for 2 days after they ended. The samples were then frozen at $-20^{\circ} \mathrm{C}$ for later determinations of immunoglobulin content, tetanus titers, and opsonic activity.

\section{COPROANTIBODIES}

The frozen stool samples were quantitatively removed from the diapers, lyophylized, ground into powder, and weighed. Ten $\mathrm{ml}$ of phosphate-buffered saline (pH 7.2) was added for each gram of dried stool, mixed for $30 \mathrm{~min}$ at room temperature, and then spun at $20,000 \times g$ at $4^{\circ} \mathrm{C}$ for $30 \mathrm{~min}$. The supernatant was removed, sterile filtered, and stored at $-70^{\circ} \mathrm{C}$ until needed.

Quantitative immunoglobulin $G, A$, and $M$ levels on these samples were performed by radial immunodiffusion (Meloy I aboratories, Springfield, VA and Kallestad Laboratories, Ch: ka, $\mathrm{MN}$ ). The radial diffusion analysis of the stool samples occasionally resulted in several faint rings, both larger and smaller than the main ring. These were attributed to fragmented IgG; only the main ring was used for analysis. Immunoelectrophoresis was performed according to the method of Scheidegger (15) with HISG or stool extract in the wells. After $2 \mathrm{hr}$ in the immunoelectrophoresis chamber, antisera to $\operatorname{IgG}, \operatorname{IgA}, \operatorname{IgM}$ and $\mathrm{F}(\mathrm{ab})_{2}$ were added to the troughs: 
OPSONIC ACTIVITY AS MEASURED BY NEUTROPHIL CHEMILUMINESCENCE

Because lot 2581 of HISG contains high antibody titer to group B streptococcus (2), this organism was chosen as the target for opsonization. Type III group B streptococcus (SS-893, supplied by the Communicable Disease Center, Atlanta, GA) was prepared and standardized according to the method of Hemming et al. (3).

The group B streptococci were opsonized by mixing $0.4 \mathrm{cc}$ with $0.1 \mathrm{cc}$ of stool extract and rotating for $40 \mathrm{~min}$ at $37^{\circ} \mathrm{C}$. The organisms were then washed twice in phosphate-buffered saline, centrifuged, and diluted to original volume before being used immediately in the chemiluminescence assay.

Chemiluminescence was performed in a liquid scintillation counter (Beckman LS 8000) in the single photon count mode with the reaction mixtures containing $0.7 \mathrm{cc}$ of polymorphonuclear leukocytes $\left(2.5 \times 10^{6} / \mathrm{cc}\right)$ and $0.3 \mathrm{cc} 5 \times 10^{8}$ of opsonized group B streptococci. All reaction vials were kept at $37^{\circ} \mathrm{C}$ in a Dubnoff shaking water bath and removed only for the brief time required for counting.

\section{TETANUS TITERS}

Tetanus antibody was determined using a modification of the indirect hemagglutination technique of Levine et al. (8).

\section{RESULTS}

\section{CLINICAL OBSERVATIONS}

No adverse effects of the oral HISG feedings were noted during the course of the study. There was no increased regurgitation of feedings, diarrhea, or other alteration in stool pattern. All infants remained clinically well and continued to gain weight (Table 1).

\section{SERUM AND STOOL IMMUNOGLOBULINS}

Serum levels of $\mathrm{IgG}$, drawn on days 0 and 5 of the study, showed a slight but insignificant fall in concentration for six of the seven infants, including the control (Table 1). Patient 5 demonstrated a small rise in $\operatorname{IgG}$. Serum $\operatorname{IgM}$ and $\operatorname{IgA}$ showed no significant change during the course of the study.

HISG lot 2581 contains $14 \mathrm{mg} / \mathrm{dl}$ of IgA and $82 \mathrm{mg} / \mathrm{dl}$ of IgM in addition to $10 \mathrm{~g} / \mathrm{dl}$ of IgG. Trace quantities of both IgM and IgA were found in all stool samples, including the control samples collected on each infant before and after the HISG feedings and in the control infant not given HISG. Levels did not rise during the HISG feedings.

No infant had measurable IgG in $24 \mathrm{hr}$ stool samples collected before initiation of immunoglobulin feedings; further, in each case, the stool IgG levels declined to negligible amounts within 48 $\mathrm{hr}$ after the last feeding. The oral HISG dosages and the maximum amounts of IgG recovered in the stools are presented in Table 2. It can be seen that $\operatorname{IgG}$ was found in the stools of all six infants fed HISG. This IgG ranged from 3 to $72 \mathrm{mg} / 24 \mathrm{hr}$ and represent 4 to $12 \%$ of the oral dose. Increasing doses or oral HISG are associated with higher amounts of IgG excreted per day, suggesting a linear relationship between the amount ingested and the amount recovered.

Table 3 provides the daily ingestion and excretion pattern over the 7 days of the study for the infant given $4 \mathrm{ml} / \mathrm{kg}$ of $\mathrm{HISG}$.

\section{DIGESTION PRODUCTS}

Pepsin digestion of $\mathrm{IgG}$ results in splitting the molecule into several smaller pieces. The primary digestion product is the $F(a b)_{2}$ fragment. Figure 1 illustrates the immunoelectrophoretic pattern of this fragment, present in the stool supernatants of two infants. Smaller, faster moving fragments are also present that react with anti whole IgG but not with anti $\mathrm{F}(\mathrm{ab})_{2}$. It is likely that the stool immunoglobulin determinations included $\mathrm{F}(\mathrm{ab})_{2}$ fragments.

\section{ACTIVITY OF STOOL IGG}

The tetanus titer of HISG lot 2581 is $1: 1024$. Tetanus antibody titers were performed on stool samples (coproantibody) from each of the six infants fed oral HISG, and in no case was the titer $>1: 8$. Most values were less than $1: 2$.

Table 1. Clinical summary and immunoglobulin levels on infants given oral human immune serum globulin

\begin{tabular}{|c|c|c|c|c|c|c|c|}
\hline \multirow[b]{3}{*}{ Patient } & \multirow[b]{3}{*}{ Sex } & \multirow{3}{*}{$\begin{array}{l}\text { Age } \\
\text { (days) }\end{array}$} & \multirow{3}{*}{$\begin{array}{l}\text { Birth wt } \\
(\mathrm{g})\end{array}$} & \multirow[t]{3}{*}{$\begin{array}{l}\text { Study wt } \\
\text { (g) }\end{array}$} & \multicolumn{3}{|c|}{$\begin{array}{l}\text { Serum immunoglobulin levels } \\
\qquad(\mathrm{mg} / \mathrm{dl})\end{array}$} \\
\hline & & & & & \multicolumn{3}{|c|}{ Study day $0 /$ study day 7} \\
\hline & & & & & $\operatorname{IgG}$ & $\operatorname{IgM}$ & $\mathrm{IgA}$ \\
\hline 1. K. F. & $M$ & 20 & 1290 & $1360 / 1540$ & $121 / 75$ & $48 / 50$ & $3 / 3$ \\
\hline 2. D. F. & $\mathrm{M}$ & 30 & 1510 & $1640 / 1930$ & $192 / 144$ & $36 / 38$ & $4 / 3$ \\
\hline 5. J.S. & $\mathrm{F}$ & 95 & 950 & $1700 / 1800$ & $470 / 500$ & $274 / 215$ & $4 / 6$ \\
\hline 6. P. C. & $\mathrm{M}$ & 26 & 1100 & $1400 / 1600$ & $300 / 300$ & $21 / 16$ & $8 / 6$ \\
\hline 7. V. G. & $\mathrm{F}$ & 54 & 860 & $1540 / 1710$ & $70 / 55$ & $26 / 30$ & $4 / 4$ \\
\hline
\end{tabular}

Table 2. Daily dose and amount recovered of IgG globulin of six infants (and one control) given oral human immune serum globulin

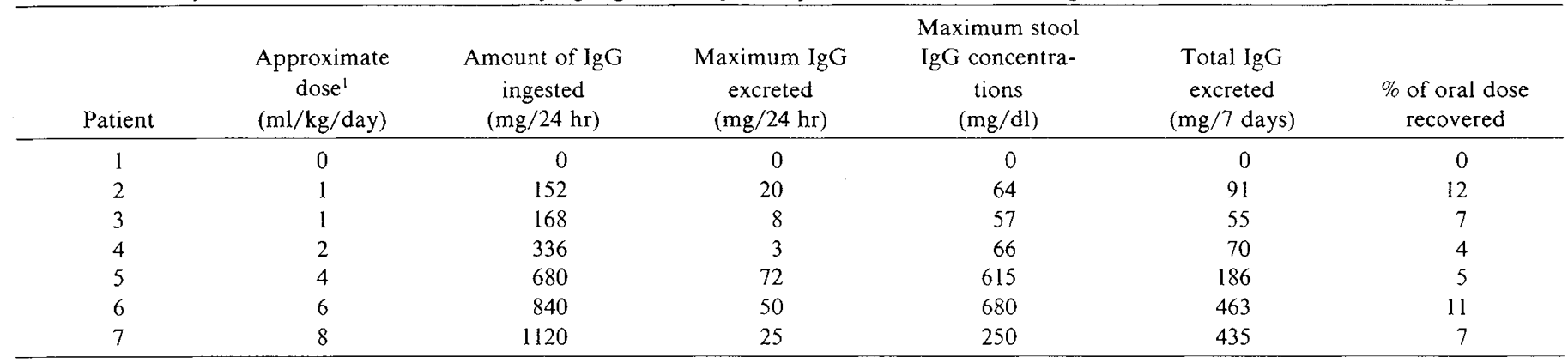

\footnotetext{
Each $\mathrm{ml}$ has $100 \mathrm{mg}$ of $\mathrm{IgG}$.
} 
Table 3. Daily IgG globulin ingestion and excretion of one infant (patient 6) fed human immune serum globulin

\begin{tabular}{|c|c|c|c|c|c|}
\hline Day & $\begin{array}{c}\text { IgG ingested } \\
(\mathrm{mg})\end{array}$ & $\begin{array}{l}\text { Dry wt of } \\
\text { stool (mg) }\end{array}$ & $\begin{array}{l}\text { IgG excretion } \\
(\mathrm{mg} / 24 \mathrm{hr})\end{array}$ & $\begin{array}{l}\% \text { of } \mathrm{IgG} \\
\text { recovered }\end{array}$ & $\begin{array}{l}\text { IgG of stool } \\
\text { supernatant } \\
(\mathrm{mg} / \mathrm{dl})\end{array}$ \\
\hline 1 & 0 & & 0 & & 0 \\
\hline 3 & 680 & 1170 & 72 & 11 & 615 \\
\hline 4 & 680 & 501 & 22.5 & 3 & 450 \\
\hline 5 & 680 & 813 & 32.5 & 5 & 400 \\
\hline
\end{tabular}

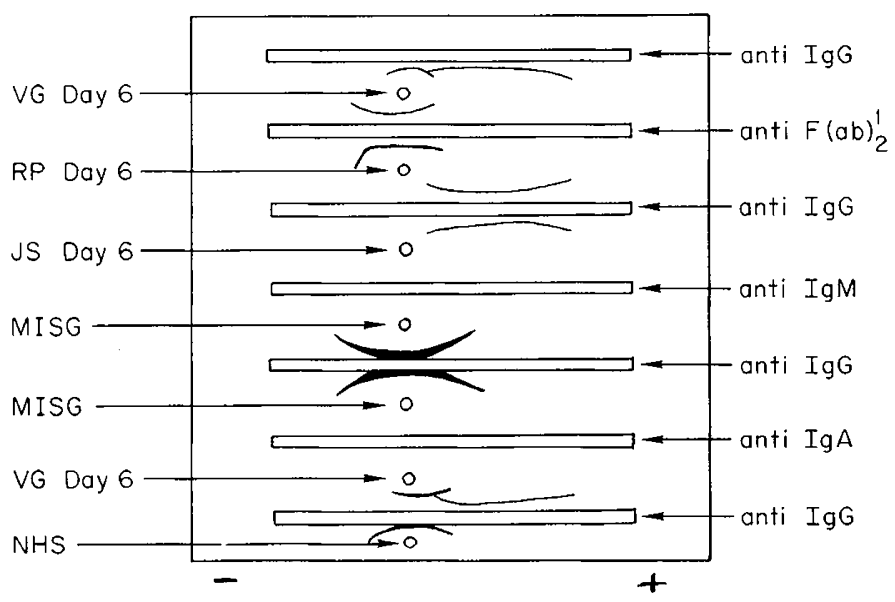

Fig. 1. Immunoelectrophoretic pattern of stools of three patients (V. G., patient, 7; R. P., patient 4; J. S., patient 5) demonstrating presence of $\mathrm{F}(\mathrm{ab})_{2}$ fragment and other fast moving digestion material of $\mathrm{IgG}$. The albumin moves toward the positive electrode on the right.

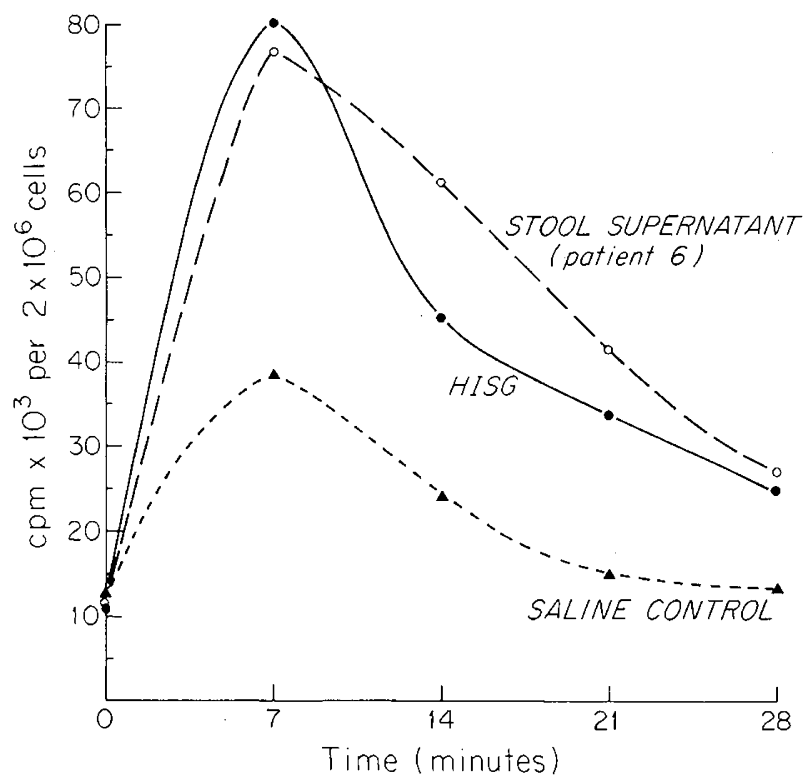

Fig. 2. CL response of normal human granulocytes to group B streptococcus opsonized by the stool supernatant of an infant fed HISG. The $\mathrm{CL}$ response to bacteria opsonized by HISG or saline are shown as positive and negative controls.

\section{OPSONIC STUDIES}

Figure 2 illustrates a representative experiment showing how the opsonic titer is determined. Normal granulocytes $\left(1.75 \times 10^{6}\right)$ are mixed with group B streptococci $\left(5 \times 10^{8}\right)$, exposed to saline, HISG, or stool supernatants from an HISG-fed infant and the chemiluminescence produced is measured over time. The peak

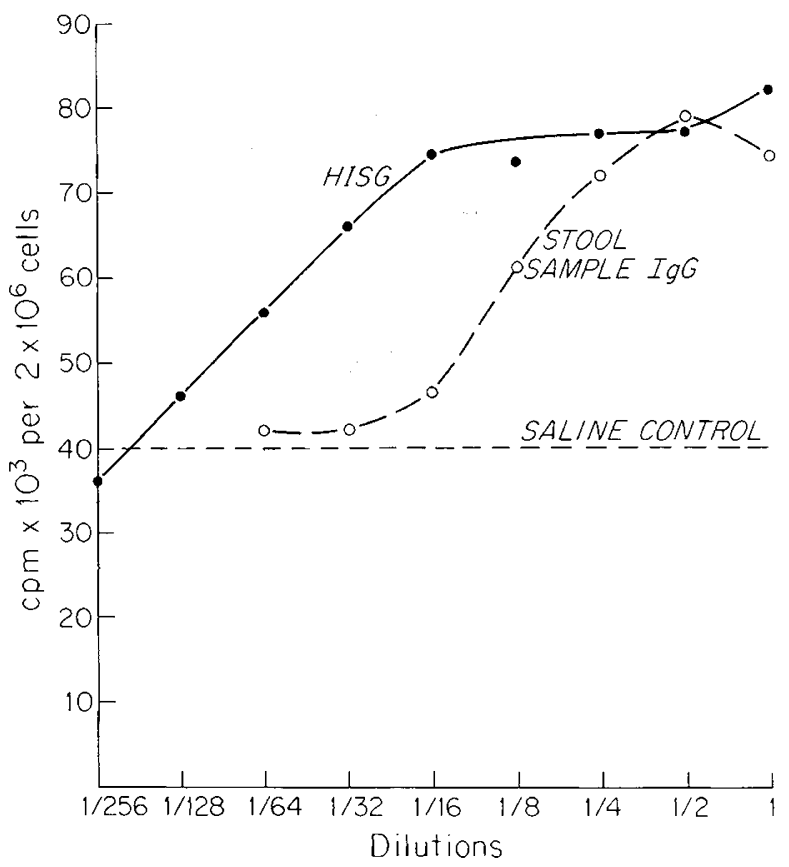

Fig. 3. The opsonic titer to group B steptococcus of a stool sample from an infant receiving oral human immune serum globulin. The stool $\mathrm{IgG}$ was $205 \mathrm{mg} / \mathrm{dl}$. The opsonic titer is measured by enhanced $\mathrm{CL}$ of normal granulocytes when the stool (or HISG or saline) is used to opsonize group $G$ streptococcus. The stool sample has almost the same opsonic activity as the orally administered HISG ( $\operatorname{lgG}=10,000 \mathrm{mg} / \mathrm{dl})$. Stools from infants not receiving oral HISG have no enhanced $\mathrm{CL}$ and remain below the saline control line.

response in cpm/2 $/ 20^{6}$ cells is used as an index of opsonic activity. This is generally reached at $7 \mathrm{~min}$ after addition of the PMNs to the reaction vial. There was then a rapid falloff in counts over the subsequent $21 \mathrm{~min}$. The curves for HISG, stools, and saline are similar in configuration, except for the peak chemiluminescence (CL) achieved.

Figure 3 illustrates the opsonic titer of HISG for Type III group B streptococcus (SS893) as determined by $\mathrm{CL}$ at dilutions of $1: 2$ to 1:256. A representative pattern from the stool of an infant fed HISG $(6 \mathrm{ml} / \mathrm{kg})$ is also shown. Stool samples with IgG levels $>100 \mathrm{mg} / \mathrm{dl}$ uniformly supported $\mathrm{CL}$ and were effective opsonins for group B streptococcus at titers ranging up to $1: 8$ or 1:16. Stool samples with IgG levels $<100 \mathrm{mg} / \mathrm{dl}$ did not opsonize type III Group B streptococcus and therefore were poorly supportive of CL. This was also true for stools from the control infant as well as for all stool samples collected before HISG feedings and $48 \mathrm{hr}$ after HISG feedings.

The CL counts and their relationship to stool $\operatorname{IgG}$ levels are shown in Figure 4. Intensity of CL response does not relate to the $\mathrm{IgG}$ level in a linear fashion. Figure 5 illustrates $\mathrm{CL}$ response on stool samples with antibody levels both above and below $100 \mathrm{mg} /$ $\mathrm{dl}$, on undiluted HISG, and on saline controls. The average CL of those samples with coproantibody levels in excess of $100 \mathrm{mg} / \mathrm{dl}$ is 


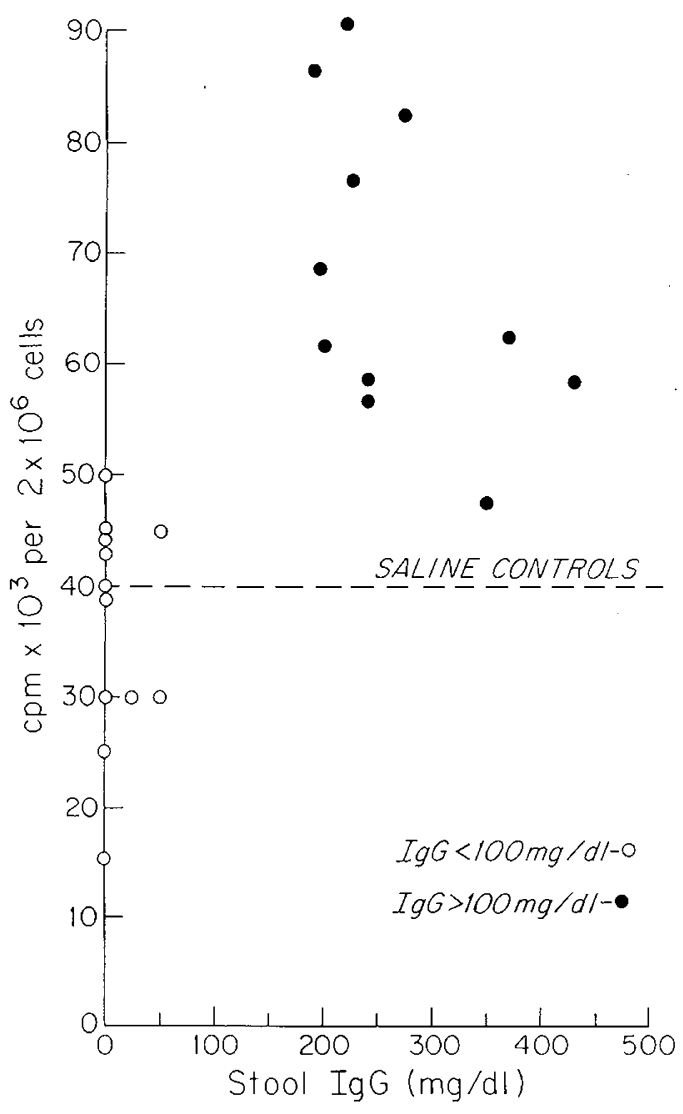

Fig. 4. Comparison of opsonic activity toward group B streptococcus of stools of infants whose stool IgG levels were less than $100 \mathrm{mg} / \mathrm{dl}(\mathrm{O})$ with those with stool $\operatorname{IgG}$ levels greater than $100 \mathrm{mg} / \mathrm{dl}$. The opsonic activity is measured by enhanced $\mathrm{CL}$ of normal granulocytes in the presence of group B streptococcus opsonized by the stool (or saline) extract.

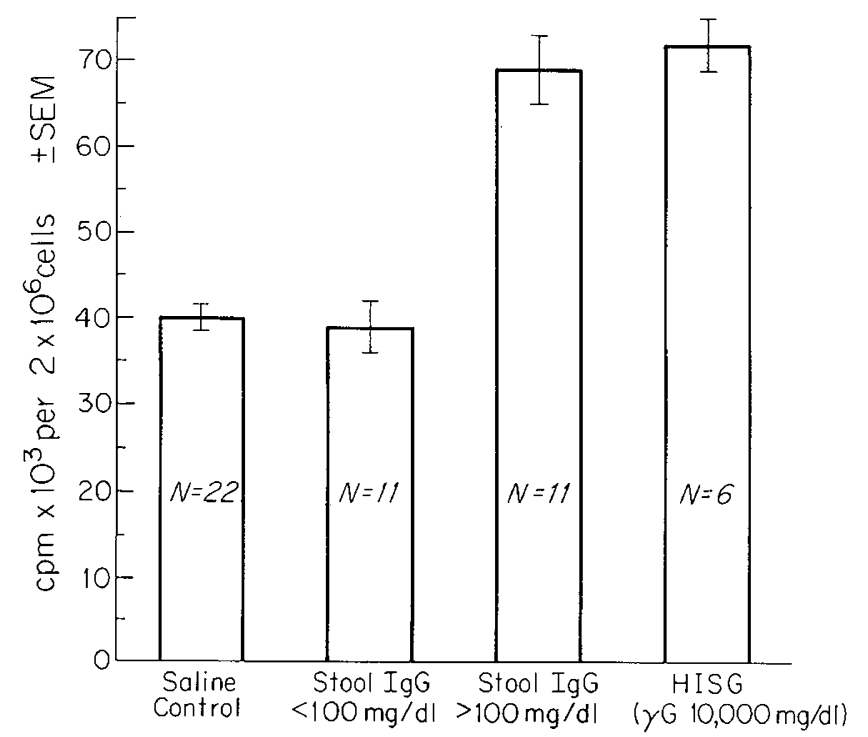

Fig. 5. Mean opsonic activity of stools of infants fed oral immune serum globulin in relation to the stool $\mathrm{IgG}$ globulin levels. Stools with $\mathrm{IgG}$ levels exceeding $100 \mathrm{mg} / \mathrm{dl}$ had opsonic titers toward group B streptococcus equivalent to HISG whereas stools with IgG less than $100 \mathrm{mg} / \mathrm{dl}$ had no significant opsonic activity.

69,000 compared with 39,000 per samples with levels less than 100 $\mathrm{mg} / \mathrm{dl}$. This difference is highly significant $(P<0.001)$.

The difference between the high $\mathrm{IgG}$ samples and the saline controls $\left(40 \times 10^{3}\right)$ is also highly significant $(P<0.001)$. No statistical difference in $\mathrm{CL}$ is found between saline controls and samples with $<100 \mathrm{mg} / \mathrm{dl}$ of $\mathrm{IgG}$ or between samples with $>100$ $\mathrm{mg} / \mathrm{dl}$ of $\mathrm{IgG}$ and HISG.

\section{DISCUSSION}

In the last decade, an increased interest in the immunologic properties of breast milk has paralleled a resurgence in breast feeding in both developing and developed countries. The antiinfective properties of human milk have been recently reviewed $(6,20)$ providing information as to why newborns in developing countries are at increased risk from infection when breast milk feedings are discontinued $(9,13)$.

The primary immunoglobulin of human milk is $\operatorname{IgA}$, present largely in its 11S secretory form. The secretory piece of this molecule confers upon it the ability to resist denaturation in the GI tract. Several authors have demonstrated that the colostral $11 \mathrm{~S}$ secretory is not absorbed from the GI tract, thus not contributing to the antibody or immunoglobulin levels of the serum $(1,11)$.

These observations as well as the studies of Rieger and Rothberg (14) demonstrating that small prematures do not form specific antibodies to oral bovine serum albumin suggested that it was extremely unlikely that our subjects would absorb the HISG or develop anti-IgG antibodies after the HISG feedings. Serum levels of IgG, IgA, and IgM drawn on days 0 and 5 of HISG feedings did not significantly change, indicating that oral absorption of HISG did not occur.

Both colostral secretory IgA and small amounts of IgG are present in the stools of breast-fed infants (18). We also found trace quantities of $\operatorname{IgG}, \operatorname{IgM}$, and $\operatorname{Ig} A$ in all stool samples, including controls, before HISG feedings, indicating that some immunoglobulin enters the GI tract through local production or transudation.

A likely mechanism for the protective action of SIgA lies in its ability to line the GI tract, preventing adherence and penetration by pathogenic organisms. Walker and Isselbacher (19) have summarized the evidence for the concept that immunoglobulins are absorbed to the epithelial cells and diminish adherence of bacteria. Although SIgA is considered by Walker (17) to be a more efficient immunologic agent than serum IgG, the latter may be equally effective if present in sufficient quantity. This has been shown to be so in studies of the adherence of Escherichia coli to human urinary tract epithelial cells (16).

We have thus posed two questions in a search for a possible colostral IgA substitute. Does orally fed human IgG resist denaturation and digestion sufficiently to be partially present in infants' stool? If present, is it functionally active?

In 2 to 4 days of breast feeding an infant ingests five $g$ of immunoglobulin. The infants in the present study were fed doses of immunoglobulin ranging from 158 to $1120 \mathrm{mg} / 24 \mathrm{hr}$ and in all cases, it was present in readily detectable amounts in their stools. The highest stool IgG ( 250 to $680 \mathrm{mg} / \mathrm{dl}$ ) concentrations appeared in infants given the larger HISG doses, but there was significant variation between babies. Factors such as GI enzymatic maturity, bowel $\mathrm{pH}$, and transit time may be responsible for these differences.

Orally administered $\mathrm{IgG}$ does appear to be functionally active. In studies with a rabbit ileal loop model, Zinkernagel and Colombini (21) showed that passive oral immunization with bovine immunoglobulin (50 mg of IgG per loop) was effective in decreasing viability of several strains of human enteropathogenic $E$. coli. Other studies $(4,7,10)$ have suggested the clinical effectiveness of bovine anti- $E$. coli milk immunoglobulin in outbreaks of human infantile gastroenteritis.

The clinical trials of Lille, France and Barcelona, Spain (4) involved 156 infants under 7 months of age with $E$. coli gastroenteritis. Administration of anti- $E$. coli colostral whey protein shortened the clinical course and speeded bacteriologic resolution of disease as compared to 43 infants fed colostral whey protein from cows not previously immunized with $E$. coli. In similar studies, Larguia et al. (7) noted that nursery outbreaks of $E$. coli gastroenteritis were prevented by human colostrum feeding. When 
colostral supplements were not given for 3 days, an outbreak occurred; this was quickly controlled by re-instituting the formula additive.

Our results show that oral HISG, when present in the stool in sufficient quantity, remains an effective opsonin for an important neonatal pathogen. Indeed, opsonic activity determined by $\mathrm{CL}$ is not statistically different from that obtained for pure HISG. Antitoxin properties, however, seem to have been severely affected as evidenced by the almost absent tetanus antibody titers in all stool samples. Liability of tetanus antibody to in vitro peptic digestion was also noted by Hilpert et al. (4). This dichotomy between antitoxic and opsonic activity may be explained by partial breakdown of the IgG molecule. Determinants with activity for tetanus may have been lost whereas other fragments may have retained activity against group B streptococci. Some breakdown of HISG into $\mathrm{F}(\mathrm{ab})_{2}$ fragments was seen in the present study, and although these normally retain antibody activity, other digestion fragments with reduced antibody activity may also have been present.

\section{REFERENCES AND NOTES}

1. Ammann, A. J., and Stiehm, E. R.: Immune globulin levels in colostrum and breast milk, and serum from formula and breast-fed newborns. Soc. Exp. Biol. Med., 122: 1098 (1966)

2. Fischer, G.: Personal communication.

3. Hemming. V. G.. Hall. R. T., Rhodes, P. G., Shigeoka, A. O., and Hill, H. R.: Assessment of group B streptococcal opsonins in human and rabbit serum by neutrophil chemiluminescence. J. Clin. Invest., 58: 1379 (1976).

4. Hilpert, H., Gerber, H., Amster, H., Pahud, J. J., Ballabriga, A., Arcalis, L., Farriaux, F., dePeyer, E., and Nussle, D.: Bovine milk immunoglobulins (Ig), their possible utilization in industrially prepared infants' milk formula. In: $\mathrm{L}$. Hambraeus, L. A. Hanson, H. McFarlane: Proceedings of a Symposium of the Swedish Medical Research Council. pp. 182-196. (Almqvist and Wiksell International, Stockholm, 1977).

5. Jelliffe, D. B.: World trends in infant feeding. Am. J. Clin. Nutr. 29: 1227 (1976).

6. Jelliffe, D. B., and Jelliffe, E. F. P.: Human Milk in the Modern World. (Oxford University Press, London 1978).

7. Larguia, A. M., Urman, J., Ceriani, J. M., O’Donnell, A., Stoliar, O., Martinez, J. C., Buscaglia, J. C., Weils, S., Quiroga, A., and Irazu, M.: Immunidad local en el recien nacido. Primera experimencia con la administration de calostro humano a recien nacidos pretermino. Arch. Argent. Pediatr. 72: 109 (1974).
8. Levine, L.. Wyman. L., Broderick, E. J., and Ipsen, J., Jr.: Field study in triple immunization (diphtheria, pertussis, tetanus); Estimation of 3 antibodies in infant sera from single heel puncture using agglutination techniques. J. Pediatr., 57: 836 (1960).

9. Mata, L. J., and Urrutia, J. J.: Intestinal colonization of breastfed children in a rural area of low socioeconomic level. Ann. N. Y. Acad. Sci., 176: 93 (1971)

10. Mietens, A., Keinhorst, H., Hilpert, H., Gerber, H., Amster, H., and Pahud, J. J.: Treatment of infantile $E$. coli gastroenteritis with specific bovine anti- $E$. coli milk immunoglobulins. Eur. J. Pediatr., I32: 239 (1979).

11. Ogra, S. S., Weintraub, D., and Ogra, P. L.: Immunologic aspects of human colostrum and milk. III. Fate and absorption of cellular and soluble components in the gastrointestinal tract of the newborn. J. Immunol, 119:245 (1977).

12. Pitt, J., Barlow. B., and Heird, W. C.: Protection against experimental necrotizing enterocolitis by maternal milk. I. Role of milk leukocytes. Pediatr. Res., 11: 906 (1977).

13. Plank, S. J., and Milanesi, M. L.: Infant feeding and infant mortality in rural Chile. Bull. WHO, 48: 203 (1973).

14. Rieger, CH.L, and Rothberg, R. M.: Development of the capacity to produce specific antibody to an ingested food antigen in the premature infant. J. Pediatr., 87: 515 (1975)

15. Scheidegger. J. J.: Une micro-methode de l'immuno-electrophorese. Int. Arch. Allergy Appl. Immunol., 7: 103 (1955).

16. Svanborg-Eden, C., and Svennerholm, A. M.: Secretory immunoglobulin A and $\mathrm{G}$ antibodies prevent adhesion of Escherichia coli to human urinary tract epithelial cells. Infect. Immun., 22: 790 (1978).

17. Walker, W. A.: Host defense mechanisms in the gastrointestinal tract. Pediatrics, 59: 901 (1976).

18. Walker, W. A., and Hong, R.: Immunology of the gastrointestinal tract. J. Pediatr., 83: 517 (1973).

19. Walker, W. A., and Isselbacher, K. J.: Intestinal antibodies. N. Engl. J. Med., 297: 767 (1977).

20. Welsh, J. K., and May, J. T.: Anti-infective properties of breast milk. J. Pediatr. 94: l (1979).

21. Zinkernagel, R. M., and Colombini, A.: Passive oral immunization with bovine immunoglobulins: Enteropathogenic $E$. coli from infants and bovine anti-E. coli lactoserum assayed in the rabbit ileal loop model. Med. Microbiol. Immunol., 162: 1, (1975).

22. The present address of Herbert J. Krantman, 777 S. New Ballas Road, Suite 102E, St. Louis, MO 63141 (USA).

23. The present address of Paul M. Blum, University of Minnesota Medical School Minneapolis, MN 55455 (USA)

24. Requests for reprints should be addressed to: Dr. E. Richard Stiehm, Department of Pediatrics, UCLA Center for the Health Sciences, Los Angeles, CA 90024 (USA).

25. This research was supported in part by Public Health Service Grants HD-09800, Al-7008, and Al-15332.

26. Received for publication August 1, 1980

27. Accepted for publication December 12, 1980. 